УДК 621:504 DOI 10.31210/visnyk2018.03.23

(C) 2018

\author{
Дмитриков В. П., доктор технічних наук, професор \\ Дудніков І. А., кандидат технічних наук, \\ Падалка В. В., кандидат технічних наук \\ Полтавська державна аграрна академія
}

\title{
РЕЦИКЛІНГ ВІДПРАЦЬОВАНИХ КОМПОНЕНТІВ АВТОТРАКТОРНОЇ ТЕХНІКИ І ТЕХНОЛОГІЧНИХ МАШИН АГРАРНИХ ВИРОБНИЦТВ
}

\section{Рецензент - доктор технічних наук О. М. Костенко}

\begin{abstract}
Визначено проблеми, щзо склалися у сфері рециклінгу відпрацьованих компонентів автотракторної техніки і технологічних машин аграрних виробництв. Проаналізовано стадії утворення вторинних матеріальних ресурсів відпрацьованих компонентів, розібрано принципи побудови $i$ компонування ліній з $і$ хх переробки. Розроблено типову схему постадійної переробки відпрацьованих компонентів на профільному переробному підприємстві з використанням принщипів інформаційних технологій і гнучких технологічних ліній.
\end{abstract}

Ключові слова: автотракторна техніка, відпрацьовані компоненти, рециклінг, технологічні машини.

Постановка проблеми. Сучасний рециклинг - динамічна область ресурсозбереження, котра швидко розвивається. Як елемент системи екологічного розвитку, рециклінг стає однією з домінант прогресу XXI століття. Рушійною силою $\epsilon$ наростаючий дефіцит природних ресурсів при загостренні екологічних аспектів проблеми відходів.

Традиційний підхід до утилізації вимагає заміни самої концепції для усунення відходів, що не переробляються, на ранніх стадіях розробки матеріальних об'єктів. Специфіка поточного періоду полягає у необхідності реалізації принципу «нуль відходів», який отримав всесвітнє визнання [5].

Залучення відходів виробництв у вторинні матеріальні ресурси (ВМР) має важливе економічне, екологічне і соціальне значення. Ліквідація відходів 3 трансформацією їх у ВМР $є$ заключною стадією життєвого циклу технічної продукції.

У даний час екологічні критерії оцінки життевого циклу технічної продукції включають можливість максимальної замкнутості вхідних і вихідних потоків, тобто вичерпного рівня переробки технічної продукції, пошук нових шляхів рециклінгу вторинних матеріальних ресурсів для кожного виду продукції [3].

Повною мірою це стосується використання відпрацьованих компонентів автотракторної техніки і технологічних машин (АТTM), що застосовуються в аграрному виробництві (автомобілі, трактори, комбайни, причепи, напівпричепи, спецтехніка та ін.).

Практично будь-який відпрацьований компонент доцільно перетворювати на корисний продукт, а з урахуванням того, що виведення з експлуатації АТТМ в світовому масштабі становить від 3 до $8 \%$, значення рециклінгу ВМР для вирішення проблем ресурсозбереження значно зростає.

Аналіз останніх досліджень і публікацій, у яких започатковано розв'язання проблеми. Утилізація металевих деталей i конструкцій АТТМ відпрацьована в достатній мірі, важче йде справа 3 неметалевими компонентами, номенклатура яких досить широка. До них належать: пластмаси (термопластичні і термореактивні), паливно-мастильні матеріали і технологічні рідини, акумулятори, скло, гумові вироби, в т.ч. автопокришки, ущільнення та ін.

У масштабах України таких відходів накопичилося безліч і накопичується дедалі більше значними темпами. Закон про автомобільний рециклінг прийнятий і успішно працює в розвинених країнах; він $є$ прибутковим бізнесом, як і знищення інших відходів, наприклад, твердих побутових відходів [1].

Згідно з Директивою ЄС, переробку відпрацьованих елементів машин і агрегатів, інших ВМР покладено на підприємства 3 випуску цих матеріалів і устаткування. В нашій країні такий підхід не реалізований і тому доводиться вирішувати проблеми переробки ВМР, виходячи 3 реальних можливостей окремих підприємств.

Утилізація відпрацьованих технічних компонентів АТТМ на підприємстві має особливе значення в аспекті збереження ресурсів, тобто при вирішенні проблем як ресурсозбереження, так i енергозбереження. При цьому поліпшуються еколого-економічні показники підприємства 3 випуску основної продукції за умови рентабельності переробки ВМР. 


\section{ТЕХНІЧНІ НАУКИ}

Серед напрямів ресурсозберігаючої утилізації відпрацьованих компонентів АТТМ все більшу увагу приділяють рециклінгу ВМР.

Результати аналізу літературних джерел з метою визначення пріоритетних напрямів розвитку технологій рециклінгу вказують на перспективність нових підходів щодо переробки відпрацьованих компонентів АТTM із застосуванням сучасних інформаційних технологій, гнучких виробничих систем, досягнень технічного прогресу $[2,4]$.

Моделювання процесів утилізації техніки в системі технічного сервісу АПК показало позитивні результати і рекомендовано до застосування на підприємствах із рециклінгу вторинних матеріальних ресурсів.

Необхідність виконання математичного моделювання, а в ряді випадків і фізичного моделювання, визначається складністю поставлених завдань і вимог щодо надійності і достовірності отриманих результатів.

Мета досліджень. Метою роботи є створення i аналіз схеми переробки відпрацьованих компонентів АТТМ із використанням принципів сучасних гнучких технологічних ліній і елементів інформаційних технологій.

Завдання досліджень: визначення і аналіз сучасних методів утилізації відпрацьованих компонентів АТТМ 3 інформаційною підтримкою методів переробки ВМР.

Матеріали і методи досліджень. Методологічну основу досліджень становить системний підхід, котрий забезпечує розгляд процесів переробки відпрацьованих компонентів АТТМ 3 використанням сучасного обладнання і принципів інформаційних технологій, що забезпечує розгляд процесу рециклінгу з урахуванням взаємозв'язків технологічних і конструктивних параметрів лінії переробки ВМР. Для вирішення поставлених завдань використовували абстрактнологічний метод.

Результати досліджень. Робота 3 утилізації ВMP, наприклад, відпрацьованого технічного продукту АТТМ, передбачає використання відомих підходів і засобів, котрі використовують для отримання заданого технічного продукту. Разом i3 тим є певні особливості, пов'язані 3 видом i/або типом технічного продукту, які також необхідно враховувати при переробці вторинного технічного ресурсу.

Удосконалення методів переробки відпрацьованих компонентів АТTМ на даний час передбачає інформаційну підтримку на всіх етапах переробки технічних продуктів, тобто дотримання принципів CALS (Continuous Acquisition and Life
Cycle Support - безперервна інформаційна підтримка життєвого циклу продукціi) [6].

Розгляду способів і процесів утилізації технічного продукту передує робота інформаційнопошукової системи (ІПС) у складі блоку інформаційних систем за визначеним вторинним ресурсом, оцінку іiі результатам роботи дає інформаційно-експертна система iз застосуванням програмного забезпечення, що потрібно зокрема для створення багаторівневої системи рециклінгу, яка включає диференціацію із урахуванням технологічних властивостей і видів впливів на переробляєму сировину, напівпродукт.

IПC працює 3 нормативними документами, які містять вимоги до збору і зберігання відпрацьованих компонентів АТTM, безпечного поводження 3 ними. Важливою стадією при цьому $є$ аналіз методик із визначення обсягів і характеристик відходів, які підлягають повторному використанню, виявлення їх класів небезпеки.

Встановлюють також витрати на збір і транспортування ВМР, наприклад, до проміжного i/або основного пункту 3 їх переробки в складі системи утилізуючих підприємств (крім великих автотранспортних господарств, обладнаних відповідними технологічними лініями), із застосуванням логістичних та інших принципів управління ресурсами.

Теж підлягає оцінці рух ВМР разом із формуванням основних потоків матеріалів, відпрацьованих у процесі експлуатації АТТМ. На підприємстві створюють інформаційну систему оперативного обліку, управління та утилізації ВМР, що утворюються на заключній стадії експлуатаціï АТTМ.

Інформаційно-аналітична система дає оцінку результатам пошуку, пропонуючи оптимальні шляхи вирішення проблеми, пов'язані, наприклад, із вибором технологічних схем і процесів, машин і обладнання для переробки ВMP, контролює роботу машин і обладнання технологічної лінії, підтримуючи при цьому їх оптимальний режим роботи.

Інформаційно-аналітична система також пов'язана 3 автоматизованою системою технологічної підготовки виробництва і, подібно до інших систем, пов'язана 3 системою забезпечення iํ функціонування. Програмне управління обладнанням здійснюють контролери, вбудовані в технологічне обладнання, котрі працюють із використанням систем типу CNC.

Блок зазначених інформаційних систем також містить базу знань для їх міжгалузевої (кластерної) інтеграції, що працює в режимі ON-LINE. 


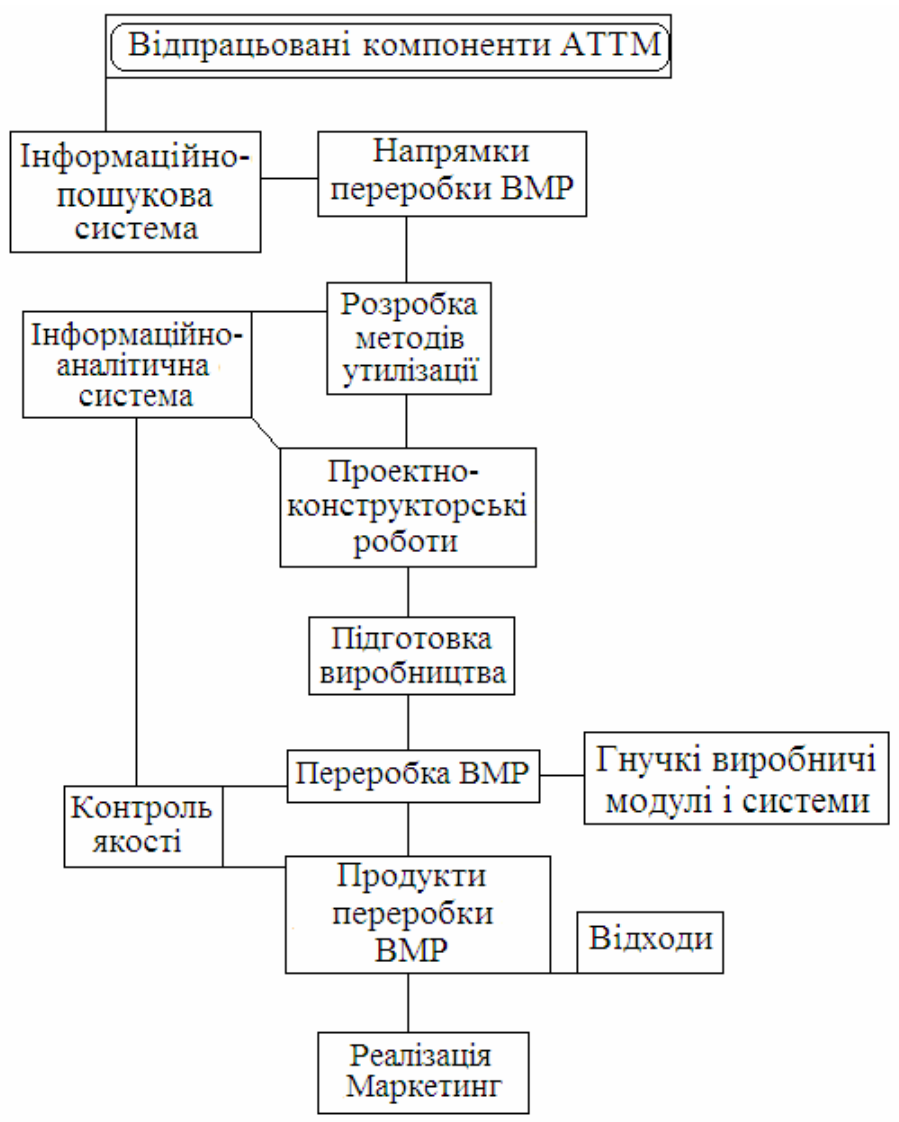

Рис. Стадії переробки відпрацьованих компонентів АТТМ

На рис. наведено типові стадії переробки відпрацьованих компонентів АТТМ.

Разом із тим у процесі переробки відпрацьованих компонентів АТТМ утворюються різні відходи, які на даному етапі розвитку інженерної науки не можуть бути перероблені в цільові продукти. Частина неутилізованих відходів підлягає рекультивації, відправленню на хвостосховища або ліквідації за наявності утилізаційних потужностей.

Висновки. Проаналізовано стадії утворення вторинних матеріальних ресурсів у кінцевому процесі життєвого циклу технічної продукції.

\section{БІБЛІОГРАФІЯ}

1. Виговська Г.П. Концептуально-методологічні засади мінімізації відходів на базі оцінювання життєвого циклу продуктів та матеріалів // Прикладна екологія. - 2013, №4. - С. 114-125.

2. Гладымев Н.Г., Быков Д.Е., Быкова Г.Л. Экологический аудит: использование корпоративных информационных систем // Экология и промышленность России. - 2004. - № 9. - С. 40-45.

3. Меллер В.Я., Жуховикий В.Б., Канщедал Е.И. Модель решения проблемы твердых бытовых отходов в Украине // Экополис, 2004. - №1(13). - С. 53-56.
Рециклінг відпрацьованих компонентів автотракторної техніки і технологічних машин із застосуванням сучасних технологій покращує еколого-економічні показники підприємства за рахунок економії матеріальних і енергетичних ресурсів. Розроблено схему рециклингу з максимальною постадійною переробкою відпрацьованих компонентів автотракторної техніки і технологгічних машин на профільному переробному підприємстві з використанням принципів інформаційних технологій і сучасних гнучких технологічних ліній.

4. Норенков И. П., Кузьмук П. К. Информационная поддержка наукоемких изделий. CALSтехнологии. - М.: Изд-во МВТУ им. Баумана, 2002. - $320 \mathrm{c}$.

5. Davidow $W$., Malone M. The virtual corporation: structuring and revitalizing the corporation for the 21st century". - N Y.: Harper Business, 1992.

6. Staudinger J. Management of End-of Life Vehicles (ELVs) in the US / J. Staudinger, G.A. Keoleian // Center for Sustainable Systems. - 2001. $-67 \mathrm{p}$. 


\section{ANNOTATION}

Dmytrykov V. P., Dudnikov I. A., Padalka V. V. Recycling of exhaust components of cars, tractors and technological machines.

The involvement of industrial waste in secondary material resources is of great economic, environmental and social importance. It fully applies to the use of waste components of cars, tractors and technological machines used in agricultural production. It is shown that after use almost any spent component can be turned into a useful product.

The stages of formation of secondary material resources of used components of cars, tractors and technological machines are analyzed, principles of construction and arrangement of lines for processing secondary resources into useful products are considered.

Improving the methods of processing the waste components of cars, tractors and technological machines now involves information support at all stages of the processing of technical products, flexible production systems, and the achievements of advanced technologies.

Simulation of the processes of utilization of machinery in the technical service system of the agro-industrial complex showed positive results and was recommended for use in recycling facilities of secondary material resources.

The methodological basis of the research is the system approach, which provides for the consideration of the processes of processing the waste components of cars, tractors and technological machines using modern equipment and the principles of information technology.

The system approach provides consideration of the recycling process taking into account the interrelations of technological and design parameters of the secondary resource processing line.

The movement of secondary resources along with the formation of the main flows of materials worked out in the course of technical operation is to be evaluated.

A scheme is offered for processing secondary material resources of cars, tractors and technological machines at a profile processing plant using the principles of information technology and flexible technological lines.

The non-recyclable part of the waste is subject to remediation or liquidation if the utilization capacity is available.

Key words: autotractor technology, spent components, recycling, technological machines. 